\title{
- Awareness Regarding COVID-19 Among Health Care Workers in a Tribal District of Chhattisgarh, India
}

IJCRR
Section: Healthcare
ISI Impact Factor
(2019-20): 1.628
IC Value (2019): 90.81
SJIF (2020) = 7.893
Cc) (7)
Copyright@IJCRR

\section{Nag S', Noor $\mathbf{S}^{2}$, Tiwari A ${ }^{3}$, Gavel $\mathbf{S}^{4}$}

'Assistant Professor, Department of Community Medicine, Late Shri Lakhiram Agrawal Memorial Medical College, Raigarh, CG, India; ${ }^{2}$ Professor, Department of Community Medicine, Late Shri Lakhiram Agrawal Memorial Medical College, Raigarh, CG, India; ${ }^{3}$ Associate Professor, Department of Community Medicine, Late Shri Lakhiram Agrawal Memorial Medical College, Raigarh, CG, India; ${ }^{4}$ Demonstrator, Department of Community Medicine, Late ShriLakhiramAgrawal Memorial Medical College, Raigarh, CG, India.

\section{ABSTRACT}

Background: Covid-19 pandemic has over 79 million cases and 1.7 million deaths globally till the last week of December 2020. Its high burden is a great concern for the entire world. The pandemic has placed extraordinary levels of physical risk \& psychological stress on health care $(\mathrm{HCW})$ workers. Addressing $\mathrm{HCW}$ knowledge, attitude \& practice is very crucial in managing the covid-19 outbreak.

Objective: Explore knowledge, attitude \& practice about Covid-19 among HCW of a tribal district in central India.

Methods: This is hospital-based cross-sectional study. 125 participants were included following convenient sampling and a selfdeveloped questionnaire was used to collect data regarding knowledge, attitude \& practice of newly appointed HCW in a tertiary care hospital in Raigarh which is a tribal district of Chhattisgarh. Knowledge, Attitude and practice score calculated and tested with socio-demographic variables.

Results: Proportion of adequate knowledge, positive attitude and good practice among participants were $41 \%, 75 \% \& 84 \%$ respectively. We found higher knowledge score for age $(9+3.49 \& 8+3.06)$, family type $(8.63 \pm 3.47 \& 7.82 \pm 2.57)$, work sector $(8.55 \pm 3.41 \& 7.68 \pm 2.24)$, education $(9.09+3.61 \& 6.33+2.06)$, profession $(9.04+3.32 \& 7.35+3.38)$ and specific work $(9.33+3.28 \& 7.86+2.93)$ in covid-19. $71 \%$ Doctors \& nurses have positive attitude comparing to $29 \%$ among nurses which is significant $(p=0.04)$.

Conclusion: HCW must be motivated by authorities to acquire adequate knowledge, a positive attitude and good practices. Knowledge attitude and practice of the health care workers is crucial in fighting the Covid-19 outbreak and authorities can empower health care workers with updated knowledge which in turn will improve their attitude and practice.

Key Words: Attitude, Health care workers, Knowledge, Ministry of Health \& Family Welfare, Practice, Quarantine, World Health Organization

\section{INTRODUCTION}

Covid-19 is currently the most challenging pandemic that has over 79 million reported cases and over 1.7 million deaths globally till the last week of December $2020 .{ }^{1}$ After the experience of the H1N1 Swine flu pandemic in 2009 that had affected more than 214 countries including over 18398 deaths. ${ }^{2}$ It has once again shifted the focus of the entire world towards the importance of communicable disease and Public health. The causative agent of Covid-19 is an enveloped, positive-sense, single-stranded Ribonucleic Acid virus that belongs to the B lineage of the beta coronavirus. ${ }^{3}$ This novel strain called SARS-Cov2 has less pathogenicity but higher transmission competence leading to the rapid increase of cases globally. ${ }^{4}$ During December 2019 almost a year back world health organization (WHO) first learned of this new virus following a series of case reports from Wuhan city, China. ${ }^{5}$ With a continuous explosive rise of cases WHO declared this outbreak as Public health emergency of international concern (PHEIC) on $30^{\text {th }}$ January 2020 and a global pandemic on March 11, 2020. ${ }^{6,7}$ Its high burden is a great concern for the entire world. As of $9^{\text {th }}$ January, 2021 total cumulative cases was 100, 566, 51 in India and 27,5042 in Chhattisgarh state. ${ }^{8}$

WHO in its press release on $17^{\text {th }}$ September 2020 empha-

\section{Corresponding Author:}

Dr. Sarat Chandra Nag, Assistant Professor, Department of Community Medicine, Late Shri Lakhiram Agrawal Memorial Medical College, Late ShriLakhiramAgrawal Memorial Medical College, Raigarh, CG, India; Mob: 8637241353; E-mail: nagdrsarat83@gmail.com

ISSN: 2231-2196 (Print)

Received: 19.02 .2021
ISSN: 0975-5241 (Online)

Revised: 09.04.2021
Accepted: 12.05 .2021
Published: 11.06 .2021 
sized the persistent threat to the health and safety of health workers in the fight against Covid -19 disease. Infection among Health workers is $14 \%-35 \%$ of total covid-19 infection reported to WHO from various countries. In addition to physical risks, the pandemic has placed extraordinary levels of psychological stress on health workers. This makes addressing health workers knowledge, attitude $\&$ practice very crucial in managing the covid- 19 outbreak. ${ }^{9}$

\section{MATERIALS AND METHODS}

\section{Study Design}

A cross-sectional study was carried out among health care workers, working in a recently inaugurated tertiary care hospital dedicated to catering to the health care needs of the Tribal population of the area.

\section{Study subject}

Our study population comprises newly joined Nurses, Doctors \& Faculties of this institute. We collected a staff list from the establishment section of our institute.

\section{Sampling technique}

Following convenient sampling, we contacted 150 persons.

\section{Patient selection}

All staffs who gave consent to participate. Patients those not using a smartphone with internet connectivity were excluded. Out of 150 twenty-five persons were excluded based on criteria and the final sample size was 125 . We have used a self-designed questionnaire to estimate study objectives.

\section{Study tool}

The questionnaire was prepared by reviewing previous articles on a similar topic and visiting websites of the Ministry of Health and Family Welfare, GOI and Indian Council of Medical Research. ${ }^{10-13}$ The questionnaire is divided into four sections: thirteen questions in section one on socio-demographic variables, ten questions in the second section for knowledge, eight questions in the third section for attitude and nine questions in the last section addressing the practice of participants. Each correct response was given a score of 1 for attitude as well as practice and in the knowledge section, each correct response assigned a score of 2. All incorrect responses were assigned zero scores each. Total possible scores are 20, 9 and 5 for knowledge, practice \& attitude respectively. Cut off score was kept to categorize each domain as 10 for $\geq 10$ for adequate knowledge, $\geq 3$ for the positive attitude and $\geq 5$ as good practice. We prepared this questionnaire as a survey form using Google docs and sent it to all participants directly in online modes like Email and WhatsApp. ${ }^{14}$ Sufficient care was taken to maintain confidentiality for participants, one participant could submit responses once only. After receipt of all 125 forms, we changed the Google docs setting to "stop receiving responses" and planned data analysis. Data was downloaded from Google docs, entered in Excel format, coding is done for variables to maintain anonymity.

\section{Data Analysis}

Descriptive statistics used to describe study variables as proportion, frequency, mean and standard deviation. Appropriate statistical tests like the Chi-square test for categorical value in $2 \times 2$ tables, student t-test for comparing means of two groups, one way ANOVA for comparing means of more than two groups, Pearson correlation test for continuous quantitative data are used for data analysis.

\section{RESULTS}

\section{Socio-demographic characteristics of partici- pants}

More than half of the participants were younger than 30 years age in the current study. The proportion of female participants is more, the male-female ratio being 1:1.19 in our study. Participants staying in the urban locality and unmarried at the time of study makes around two-thirds of all. Again it was noted that most of them resides in the nuclear family and working in government facilities. Nearly half of the participants have completed MBBS \& around onefourth comprised of recently graduated BSc nurses. About $50 \%$ of participants were frontline worker which is defined as health care workers involved directly in inpatient treatment, handling of patient's sample or dealing with biomedical wastes of the patient. ${ }^{15}$ Around $60 \%$ were involved in special tasks of Covid-19 management that include the screening of Covid-19 suspected, working in RTPCR or treat laboratory, treatment of admitted Covid patients at Covid care centre or Dedicated Covid hospital of our institute. Almost $70 \%$ at present didn't have a risk factor for corona infection such as diabetes mellitus, hypertension, smoking, under-nutrition, obesity, immune-compromised state. ${ }^{16} \mathrm{~A}$ high level i.e. $83 \%$ use of the private vehicle for transportation by participants could be due to the effect of lockdown and awareness about social distancing. Around one-third of participants reported covid-19 incidence in their locality in the past fourteen days as can be seen in Table 1. We asked for the local outbreak in the previous fourteen days because it is recommended duration of quarantine as recommended by Centres for disease control \& prevention, Atlanta, USA. ${ }^{17}$ The proportion of adequate knowledge, positive attitude and good practices found in this study was $41 \%, 75 \% \& 84 \%$ respectively. 


\section{Knowledge \& associated variables}

Knowledge was associated with other variables. We found a higher knowledge score of $9 \pm 3.49$ among older participants compared to younger participants with a score of $8 \pm 3.06$. knowledge level of participants was not found to vary much in regards to factors like gender, marital status, frontline worker, rural or urban residence, mode of daily transport and participants awareness about local outbreak. On the other hand variables like nuclear family, working in government facilities, higher education, doctor profession and specific area of work in covid-19 resulted in higher mean knowledge score as can be seen in Table 2. However, these differences are not significant statistically when appropriate statistical tests like student t-test and one-way ANOVA was applied.

\section{Attitude and associated variables}

The proportion of positive attitude and good practice was $78 \%$ \& 88\% among those above 30 years age whereas this proportion was only $73 \%$ \& $80 \%$ among participants aged less than 30 years. Around $71 \%$ of Doctors \& nurses have a positive attitude in comparison to only $29 \%$ proportion of positive attitude among nursing student and teaching faculties. It was found statistically significant at $p=0.04$ in the chisquare test. The difference in attitude and practice was also seen due to variables like the specific task, government institutes, doctor designation, but these differences are not found significant statistically. Appropriate questions were asked to access Knowledge on prevention, discharge policy and clinical management as shown in figure 1. Maximum number of participants correctly answered the question on filtration size of N-95 filter where a poor correct rate was seen for the question on RTPCR testing of moderate Covid-19 patient before discharge. ${ }^{18,19}$ Pearson correlation test was applied on participants knowledge, attitude and practice and a weak positive correlation were found as seen in Table 3.

\section{DISCUSSION}

The study was conducted from July to October 2020 among health care providers who had then recently joined a tertiary care hospital in Chhattisgarh. In our study, correct knowledge regarding Covid-19 was $41 \%$ which was lower than other studies where $70 \%-80 \%$ proportion of participants reported correct knowledge. ${ }^{20-22}$ The reason for the present study finding was the inclusion of junior doctors and nursing trainees in our current study. Furthermore, more focus was laid on clinical components of Covid care in the questionnaire, which may have resulted in a lower result. Another study among HCW using a 23 item self-designed questionnaire reported correct knowledge among sixty-one per cent of study subjects. ${ }^{23}$

A study was done at a cardiology hospital in Nepal also reported correct knowledge of 57\% among physician and 54\% among nurses. ${ }^{24}$ Another study among Chinese residents using Wenjuanxil electronic platform for data collection reported a $61 \%$ score in this domain which was higher than our study. ${ }^{25}$

So far as the attitude domain is concerned we found $76 \%$ proportion of participants having a positive attitude about the Covid-19 pandemic. Our finding was higher than a study on tertiary care hospital staffs of Nepal that reported only $53 \%$ positive attitude. ${ }^{26} \mathrm{~A}$ comparable result of $68 \%$ was reported from an online survey conducted in Vietnam. ${ }^{27}$ However another study on Chinese residents reported a $90 \%$ positive attitude which was more than our findings. Such difference is attributed to the inclusion of generalized questions like successful control of Covid-19, confidence of winning the Covid-19 battle in their questionnaire. ${ }^{28}$ Another study among adolescent of Bangladesh also reported $62 \%$ which was lower than the current study. ${ }^{29}$

The findings of $84 \%$ good practice in the current study are comparable to a study among residents of China (89\%) where they used a self-administered questionnaire to estimate knowledge, attitude and practice among participants. ${ }^{10}$ Another study from Pakistan conducted during July 2020, reported a similar result of $88 \%$ about the correct use of the medical mask. ${ }^{11}$ Among medical students of Uganda only $57 \%$ of good practice was reported in a previous study. ${ }^{30,31}$ Regarding the source of information for Covid-19 nearly $84 \%$ of participants have used authentic sources like the ministry of Health and Family Welfare guidelines and didn't rely only on social media messages. The lower findings in the knowledge component are unfortunate among HCW and higher health authorities need to encourage HCW by providing useful and concise guidelines and limiting the practice of using multiple guidelines from multiple sources.

A lower knowledge level was also seen in a study by Hadil \& co done in Riyadh, Saudi Arabia. ${ }^{31}$ During Middle East Respiratory Synicitial (MERS) outbreak similar results were seen in a study from Riyadh, UAE, Vietnam and Uganda. ${ }^{32-35}$ The present study found that persons with higher education scored more in the knowledge domain comparing others. Similar findings can also be seen in previous studies. ${ }^{28,36-39}$ Certain questions in our survey could be answered correctly by few participants only. For example, only $29 \%$ correctly answered about mask use \& isolation criteria for Covid-19 suspects. A study from India reported $40 \%$ knowledge among health staffs regarding the use of the medical mask. ${ }^{40}$ Updated guidelines on medical masks can be seen in the WHO guideline which was updated on $1^{\text {st }}$ December $2020 .{ }^{41}$ Another study done in Mumbai, India also reported $79 \%$ correct habit for mask use and disposal. ${ }^{42}$

About $90 \%$ of study participants shown adequate knowledge regarding the discharge policy of corona patient. This matches to successful completion of prior training by $90 \%$ 
of our participants. More than $80 \%$ practised four times daily handwashing with soap and water. One study among adolescent of Poland has found a similar frequency of handwashing. ${ }^{43}$ More than $90 \%$ of participants reported minimum five-time daily use of hand sanitiser is on par with findings from Saudi Arabia ${ }^{43-45}$ Prophylaxis from Covid-19 by using Hydroxychloroquine (HCQ) was found among $35 \%$ of participants. A previous study among physicians in Romania reported similar findings of $48 \% .{ }^{45}$ Only $50 \%$ usage of HCQ was seen in an Indian study. The lower proportion of HCQ prophylaxis may be due to its unproven efficacy and potential side effects.

\section{CONCLUSION}

Health care workers irrespective of their designation should be provided with Covid 19 related information frequently by using the available mode of education like Online classes, what's app group etc. Authorities should plan to collect feedback from HCWs about Covid knowledge and those HCWs with deficient knowledge must be given focus for knowledge acquisition by different participatory approach. A high standard of attitude and practices has to be maintained by motivating workers using various approaches like financial incentive, compensatory leave, early diagnosis and treatment in case of any illness, health insurance, occupational safety and welfare etc.

CONFLICT OF INTEREST: No conflict of interest was observed or likely to be observed between Authors and other stakeholders in content, method or any other area of work related to this research.

SOURCE OF FUNDING: The research work did not involve any source of funding.

\section{AUTHOR CONTRIBUTION:}

Nag S: conceptualization, methodology, data collection, software use, data analysis, writing original draft, writing review and editing. Noor S: methodology, data collection, drafting, editing. Tiwari A: data collection, writing the original draft.Gavel S: Data collection, statistical analysis

ETHICAL CLEARANCE: The study was cleared by Institutional Ethics Committee bearing letter-number sno/Med/ Ethics commit./2021/48 dated 16/02/2021.

\section{ACKNOWLEDGEMENT}

Authors acknowledge the immense help received from the scholars whose articles are cited and included in references of this manuscript. The authors are also grateful to authors/ editors/publishers of all those articles, journals and books from where the literature for this article has been reviewed and discussed.

\section{REFERENCES}

1. World Health Organization. Home, Publications, Overview, Covid-19 weekly epidemiological reports, updated on $29^{\text {th }}$ December 2020, Accessed 09 ${ }^{\text {th }}$ January 2021. Available from https://www.who.int/publications/m/item/weekly-epidemiological-update---29-december-2020

2. World Health Organization, Emergency preparedness, disease outbreak news, Pandemic (H1N1) 2009 response, weekly update, 111, updated on $30^{\text {th }}$ July 2009. Accessed $09^{\text {th }}$ January 2021. Available from https://www.who.int/csr/don/2010_07_30/en/

3. Li H, Liu SM, Yu XH, Tang SL, Tang CK. Coronavirus disease 2019 (COVID-19): current status and future perspective. Int J Antim Age. 2020:105951.

4. Zhu H, Wei L, Niu P. The novel coronavirus outbreak in Wuhan, China. Global health research and policy. 2020;5(1):1-3.

5. Sun J, He WT, Wang L, Lai A, Ji X, Zhai X, et al. COVID-19: epidemiology, evolution, and cross-disciplinary perspectives. Tren Molec Med. 2020;21(3):462.

6. Cucinotta D, Vanelli M. WHO declares COVID-19 a pandemic. Acta Bio Medica: Atenei Parmensis. 2020;91(1):157.

7. Ministry of Health \& Family Welfare, Govt. of India, Covid 19 state wise status, updated for $09^{\text {th }}$ January 2021. Accessed $09^{\text {th }}$ January 2021, 08:00 IST(GMT+5:30). Available from https:// www.mohfw.gov.in/

8. World Health Organization, Covid 19, Virtual Press Conference $17^{\text {th }}$ September 2020. Accessed 09 $9^{\text {th }}$ January 2021. Available from https://www.who.int/docs/default-source/coronaviruse/ transcripts/who-audio-emergencies-coronavirus-press-conference-17sep2020.pdf?sfvrsn=bf5ec148_2

9. Zhou M, Tang F, Wang Y, Nie H, Zhang L, You G, et al. Knowledge, attitude and practice regarding COVID-19 among health care workers in Henan, China. J Hosp Infect. 2020 105(2):183187.

10. Kumar J, Katto MS, Siddiqui AA, Saito B, Jamil M, Rasheed N, et al. Knowledge, Attitude, and Practices of Healthcare Workers Regarding the Use of Face Mask to Limit the Spread of the New Coronavirus Disease (COVID-19). Cureus. 2020;12(4).

11. Wahed WY, Hefzy EM, Ahmed MI, Hamed NS. Assessment of knowledge, attitudes, and perception of health care workers regarding COVID-19, a cross-sectional study from Egypt. J Community Health. 2020;45(6):1242-1251.

12. Indian Council of Medical research. Department of Health Research, Ministry of Health \& Family Welfare, Govt. of India Advisory, Newer additional strategies for Covid -19 testing, dated $23^{\text {rd }}$ June 2020. Accessed $08^{\text {th }}$ January 2021. Available from https://www.icmr.gov.in/cteststrat.html

13. Online survey tools using google docs. Available from https:// docs.google.com/forms $/ \mathrm{u} / 0 /$

14. Chersich MF, Gray G, Fairlie L, Eichbaum Q, Mayhew S, Allwood B, English R, Scorgie F, Luchters S, Simpson G, Haghighi MM. COVID-19 in Africa: care and protection for frontline healthcare workers. Globaliz Health. 2020;16:1-6.

15. Rod JE, Oviedo-Trespalacios O, Cortes-Ramirez J. A brief-review of the risk factors for covid-19 severity. Revista de Saúde Pública. 2020;54:60.

16. Centres for Disease Control \&Prevention, Department of Health and Human Sevices, U.S., Covid -19, Your health, When to quarantine. Available from https://www.cdc.gov/coronavirus/2019ncov/if-you-are-sick/quarantine.html

17. Qian Y, Willeke K, Grinshpun SA, Donnelly J, Coffey CC. Performance of N95 respirators: filtration efficiency for airborne microbial and inert particles. Am Industr Hyg Assoc J. 1998;59(2):128-132. 
18. Ministry of Health \& Family Welfare, Govt. of India, Clinical management protocol, Covid-19, version 05, dated $03^{\text {rd }}$ july 2020. Available from https://www.mohfw.gov.in/pdf/UpdatedClinicalManagementProtocolforCOVID19dated03072020.pdf

19. Sari DK, Amelia R, Dharmajaya R, Sari LM, Fitri NK. Positive correlation between general public knowledge and attitudes regarding COVID-19 outbreak 1 Month after first cases reported in Indonesia. J Comm Health. 2020;24:1-8.

20. Reuben RC, Danladi MM, Saleh DA, Ejembi PE. Knowledge, attitudes and practices towards COVID-19: an epidemiological survey in North-Central Nigeria. J Comm Health. 2020;25:1-4.

21. Bhagavathula AS, Aldhaleei WA, Rahmani J, Mahabadi MA, Bandari DK. Novel coronavirus (COVID-19) knowledge and perceptions: a survey on healthcare workers. MedRxiv. 2020;21(6):253-259.

22. Bhandari S, Sharma M, Shrestha GS. Knowledge of COVID-19 among health care workers at a tertiary care hospital of Nepal: A descriptive cross-sectional study. J Nep Med Assoc. 2020;58(231):905.

23. Yue S, Zhang J, Cao M, Chen B. Knowledge, attitudes and practices of COVID-19 among urban and rural residents in China: a cross-sectional study. J Comm Health. 2020;15:1-6.

24. Limbu DK, Piryani RM, Sunny AK. Healthcare workers' knowledge, attitude and practices during the COVID-19 pandemic response in a tertiary care hospital of Nepal. PloS One. 2020;15(11):e0242126.

25. Van Nhu H, Tuyet-Hanh TT, Van NT, Linh TN, Tien TQ. Knowledge, attitudes, and practices of the Vietnamese as key factors in controlling COVID-19. J Comm Health. 2020;45(6):1263-1269.

26. Zhong BL, Luo W, Li HM, Zhang QQ, Liu XG, Li WT, et al. Knowledge, attitudes, and practices towards COVID-19 among Chinese residents during the rapid rise period of the COVID-19 outbreak: a quick online cross-sectional survey. Int J Biol Sci. 2020;16(10):1745.

27. Ferdous MZ, Islam MS, Sikder MT, Mosaddek AS, ZegarraValdivia JA, Gozal D. Knowledge, attitude, and practice regarding COVID-19 outbreak in Bangladesh: An online-based crosssectional study. PloS One. 2020;15(10):e0239254.

28. Olum R, Kajjimu J, Kanyike AM, Chekwech G, Wekha G, Nassozi DR, et al. Perspective of medical students on the COVID-19 pandemic: survey of nine medical schools in Uganda. J Med Int Res. 2020;6(2):e19847.

29. Alahdal H, Basingab F, Alotaibi R. An analytical study on the awareness, attitude and practice during the COVID-19 pandemic in Riyadh, Saudi Arabia. J Infec Publ Health. 2020;13(10):14461452.

30. Almutairi KM, Al Helih EM, Moussa M, Boshaiqah AE, Saleh Alajilan A, Vinluan JM, et al. Awareness, attitudes, and practices related to coronavirus pandemic among Public in Saudi Arabia. Fam Comm Heal. 2015;38(4):332-340.

31. Rabbani SA, Mustafa F, Mahtab A. Middle East Respiratory Syndrome (MERS): Awareness among Future Health Care Providers of United Arab Emirates. Int J Med Public Health. 2020;10(1).

32. Huynh G, Nguyen TN, Vo KN, Pham LA. Knowledge and attitude toward COVID-19 among healthcare workers at District 2 Hospital, Ho Chi Minh City. Asian Pac J Trop Med. 2020;13(6):260.
33. Olum R, Chekwech G, Wekha G, Nassozi DR, Bongomin F. Coronavirus Disease-2019: Knowledge, Attitude, and Practices of Health Care Workers at Makerere University Teaching Hospitals, Uganda. Front Public Health. 2020;8:181.

34. Al-Mohrej OA, Al-Shirian SD, Al-Otaibi SK, Tamim HM, Masuadi EM, Fakhoury HM. Is the Saudi public aware of Middle East respiratory syndrome? J Inf Public Health. 2016;9(3):259266.

35. Abdelhafiz AS, Mohammed Z, Ibrahim ME, Ziady HH, Alorabi M, Ayyad M, et al. Knowledge, perceptions, and attitude of Egyptians towards the novel coronavirus disease (COVID-19). J Comm Health. 2020;45(5):881-890.

36. Wolf MS, Serper M, Opsasnick L, O'Conor RM, Curtis L, Benavente JY, Wismer G, Batio S, Eifler M, Zheng P, Russell A. Awareness, attitudes, and actions related to COVID-19 among adults with chronic conditions at the onset of the US outbreak: a cross-sectional survey. Ann Int Med. 2020;173(2):100-109.

37. Singh DR, Sunuwar DR, Karki K, Ghimire S, Shrestha N. Knowledge and perception towards universal safety precautions during early phase of the COVID-19 outbreak in Nepal. J Comm Health. 2020;45:1116-1122.

38. Parikh PA, Shah BV, Phatak AG, Vadnerkar AC, Uttekar S, Thacker N, Nimbalkar SM. COVID-19 pandemic: knowledge and perceptions of the public and healthcare professionals. Cureus. 2020;12(5).

39. World Health Organization, coronavirus disease ( Covid -19), Masks , Q \& A, updated $01^{\text {st }}$ December 2020. Accessed 09 ${ }^{\text {th }}$ January 2021. Available from https://www.who.int/emergencies/diseases/novel-coronavirus-2019/question-and-answershub/q-a-detail/coronavirus-disease-covid-19-masks

40. Modi PD, Nair G, Uppe A, Modi J, Tuppekar B, Gharpure AS, et al. COVID-19 awareness among healthcare students and professionals in Mumbai metropolitan region: a questionnaire-based survey. Cureus. 2020;12(4).

41. Głąbska D, Skolmowska D, Guzek D. Population-based study of the influence of the COVID-19 pandemic on hand hygiene behaviours-Polish adolescents' COVID-19 experience (PLACE-19) study. Sustainability. 2020;12(12):4930.

42. Alsatian MS, Abuyassin AH, Alsaeed ZH, Alshmmari SH, Bindaaj TF, Alhababi AA. The Prevalence and Determinants of Hand and Face Dermatitis during COVID-19 Pandemic: A Population-Based Survey. Derm Res Pract. 2020;2020:6627472

43. Baucus C, Pinte L, Stoichitoiu LE, Badea C. Hydroxychloroquine for prophylaxis of COVID-19 physicians survey: Despite lack of evidence, many would take or give to dear ones, and despite the perceived necessity of an RCT, few would participate. J Eva Clin Pract. 2020;26(6):1579-1582.

44. Bhattacharya R, Chowdhury S, Mukherjee R, Nandi A, Kulshrestha M, Ghosh R, Saha S. Pre-exposure hydroxychloroquine prophylaxis for covid-19 in healthcare workers: a retrospective cohort. Int J Res Med Sci. 2021. Online ahead of print. doi: 10.18203/2320-6012.ijrms20205444

45. Chen Z, Hu J, Zhang Z, Jiang S, Han S, Yan D, Zhuang R, Hu B, Zhang Z. Efficacy of hydroxychloroquine in patients with COVID-19: results of a randomized clinical trial. MedRxiv. 2020 Jan 1. DOI: $10.1101 / 2020.03 .22 .20040758$. 
Table 1: Participants mean knowledge score by socio-demographic variables

\begin{tabular}{|c|c|c|c|c|c|c|}
\hline $\begin{array}{l}\text { SI } \\
\text { no }\end{array}$ & Variable & category & Number (\%) & $\begin{array}{l}\text { Knowledge score } \\
\text { (mean,sd) }\end{array}$ & P value & $\begin{array}{c}\text { Statistical } \\
\text { test }\end{array}$ \\
\hline \multirow[t]{3}{*}{1} & \multirow{3}{*}{ Age group } & & & & & $\mathrm{t}$ test \\
\hline & & Bellow 30 yrs & $73(58 \%)$ & $8+3.06$ & 0.09 & -1.7 \\
\hline & & Above 30 yrs & $52(42 \%)$ & $9+3.49$ & & \\
\hline \multirow[t]{3}{*}{2} & \multirow[t]{3}{*}{ Sex } & & & & & $\mathrm{t}$ test \\
\hline & & Male & $57(45 \%)$ & $8.67+3.61$ & 0.43 & 0.78 \\
\hline & & female & $68(55 \%)$ & $8.21+2.96$ & & \\
\hline \multirow[t]{3}{*}{3} & \multirow[t]{3}{*}{ Marital status } & & & & & t test \\
\hline & & Married & $49(39 \%)$ & $8.19+3.12$ & 0.37 & 0.88 \\
\hline & & Unmarried & $76(61 \%)$ & $8.72+3.47$ & & \\
\hline \multirow[t]{3}{*}{4} & \multirow[t]{3}{*}{ Address } & & & & & t-test \\
\hline & & Urban & $94(75 \%)$ & 8.513 .29 & 0.57 & 0.56 \\
\hline & & Rural & $31(25 \%)$ & 8.133 .22 & & \\
\hline \multirow[t]{3}{*}{5} & \multirow[t]{3}{*}{ Family type } & & & & & t-test \\
\hline & & Nuclear & $92(73 \%)$ & 8.633 .47 & 0.22 & 1.22 \\
\hline & & Joint & $33(27 \%)$ & 7.822 .57 & & \\
\hline \multirow[t]{3}{*}{6} & \multirow[t]{3}{*}{ Working sector } & & & & & t-test \\
\hline & & Govt. & $106(85 \%)$ & 8.553 .41 & 0.29 & 1.06 \\
\hline & & Private & $19(15 \%)$ & $7.68 \quad 2.24$ & & \\
\hline \multirow[t]{5}{*}{7} & \multirow[t]{5}{*}{ Education } & & & & & One way \\
\hline & & MBBS & $56(45 \%)$ & $8.64+3.35$ & 0.07 & Anova \\
\hline & & $\mathrm{MD} / \mathrm{MS}$ & $33(26 \%)$ & $9.09+3.61$ & & 2.39 \\
\hline & & $\mathrm{BSc} / \mathrm{Msc}$ & $24(19 \%)$ & $8.00+2.70$ & & \\
\hline & & 12th & $12(10 \%)$ & $6.33+2.06$ & & \\
\hline \multirow[t]{5}{*}{8} & \multirow[t]{5}{*}{ Current post } & & & & & One-way \\
\hline & & Doctor & $63(53 \%)$ & $9.04+3.32$ & 0.09 & Anova \\
\hline & & Nurse & $16(12 \%)$ & $7.60+1.88$ & & 2.14 \\
\hline & & Student & $33(25 \%)$ & $7 \cdot 35+3.38$ & & \\
\hline & & $\begin{array}{l}\text { Faculty \& Administra- } \\
\text { tive }\end{array}$ & $13(10 \%)$ & $8.71+3.64$ & & \\
\hline \multirow[t]{3}{*}{9} & \multirow[t]{3}{*}{ Frontline worker } & & & & 0.45 & t-test \\
\hline & & Yes & $72(58 \%)$ & $8.39+3.05$ & & -.107 \\
\hline & & No & $53(42 \%)$ & $8.45+3.47$ & & \\
\hline \multirow[t]{5}{*}{10} & \multirow[t]{5}{*}{ Specific task } & & & & & \\
\hline & & Screening & $27(22 \%)$ & $9.33+3.28$ & & One way \\
\hline & & Sampling \& testing & $14(11 \%)$ & $8.85+4.05$ & 0.29 & Anova \\
\hline & & Treatment & $39(31 \%)$ & $8.25+3.28$ & & 1.25 \\
\hline & & $\begin{array}{l}\text { Not yet involved in } \\
\text { specific Covid work }\end{array}$ & $45(36 \%)$ & $7.86+2.93$ & & \\
\hline \multirow[t]{3}{*}{11} & Risk factor & & & & 0.22 & t-test \\
\hline & & Present & $39(31 \%)$ & $7.9+3.04$ & & -1.2 \\
\hline & & Absent & $86(69 \%)$ & $8.66+3.36$ & & \\
\hline 12 & Mode of travel & & & & & t-test 0.17 \\
\hline & & Private & $104(83 \%)$ & $8.46+3.34$ & 0.85 & \\
\hline & & public & $21(17 \%)$ & $8.32+3.07$ & & \\
\hline 13 & Corona cases & & & & & t-test 0.60 \\
\hline & nearby & Yes & $42(33 \%)$ & $8.67+2.75$ & 0.27 & \\
\hline & & No & $83(67 \%)$ & $8.29+3.51$ & & \\
\hline 14 & Attitude & Positive(score >3) & 94 & $8.48+3.21$ & 0.72 & Chi square \\
\hline & & Negative (score <3) & 31 & $8.20+3.5$ & & 0.14 \\
\hline 15 & Practice & Good (score>5) & 105 & $8.44+3.3$ & 0.93 & Chi-square \\
\hline & & Poor (score<5) & 20 & $8.3+3.13$ & & 0.006 \\
\hline
\end{tabular}


Table 2: Correlation between Knowledge, attitude and practice score of study participants

\begin{tabular}{llccc} 
Variable & & Knowledge & Attitude & Practice \\
Knowledge & Correlation coefficient(r) & 1 & 0.083 & 0.042 \\
& $p$ value & & 0.357 & 0.657 \\
Attitude & Correlation coefficient(r) & 0.083 & 1 & 0.102 \\
& $p$ value & 0.357 & & 0.257 \\
Practice & Correlation coefficient(r) & 0.042 & 0.102 & 1 \\
& $p$ value & 0.657 & 0.257 & \\
\hline
\end{tabular}

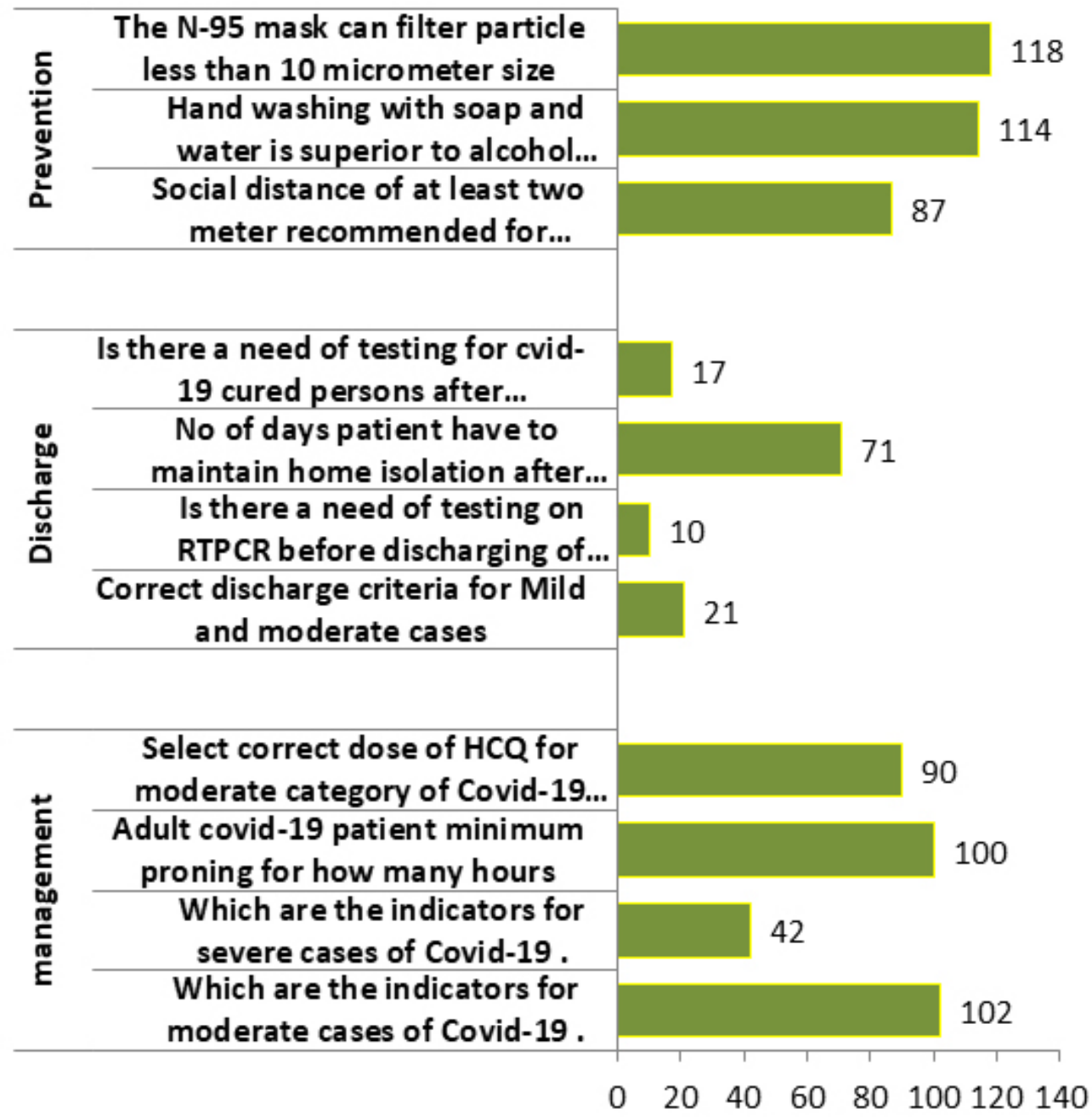

Figure 1: Knowledge of participants about prevention, discharge and management of Covid-19 patient. 